\title{
The Effect of Heating Schedule on Physico- Chemical Properties of Instant Coffee of Liberika Tungkal Jambi
}

\author{
Mursalin Mursalin*, Addion Nizori, Irma Rahmayani \\ \# Departmen of Agricultural Technology, Universitas Jambi, Kampus Pondok Meja Jl Tribrata Km 11, Jambi, 36361, Indonesia \\ E-mail:mursalin@unja.ac.id
}

\begin{abstract}
The making of instant brewed coffee using co-crystallization method is strongly influenced by the heating schedule (HS) applied. Five levels of HS (HS1, HS2, HS3, HS4 and HS5) were studied on the physico-chemical properties of instant coffee of Liberika Tungkal Jambi. The treatment was applied in a completely randomized design with 4 replications. The coffee was extracted using a special coffee extractor in a ratio of hot water/coffee powder of 15/1. Parameters observed were moisture content, ash content, $\mathbf{p H}$, solubility, and total dissolved solids. The data obtained were analyzed using ANOVA and DNMRT at 5\% significance. The results showed that the physico-chemical properties of instant coffee had significant effect on moisture content, pH, solubility, and total dissolved solids but not on ash content. The optimal HS to produce Liberika Tungkal Jambi instant coffee with good quality was heating at $1100 \mathrm{C}$ in the beginning, followed by $900 \mathrm{C}$ at the initiation of crystallization, and $750 \mathrm{C}$ when crystal growth (HS3). HS3 produces instant coffee with water content 1.57-1.61\%; ash content 6.12-6.16; pH 5.50-5.56; solubility 98.22-98.25; and total dissolved solids 8.47-8.53\% Brix.
\end{abstract}

Keywords - crystal growth, instant coffee, libtukom, recrystallization,

\section{INTRODUCTION}

Instant drinks are categorized as processed food products in the form of powder that easily soluble in water, quickly in serving, and having long shelf life $[1,2]$. One simple and inexpensive technology for producing instant drinks is through the process of co-crystalization. In this technique, the crystallization agent commonly used is sucrose. Some advantages of using sucrose as a coating agent are that they are relatively cheap, easy to be obtained, quickly dissolved, relatively stable to heat, not hygroscopic, and have a long shelf life at room temperature [3].

The making of instant coffee in this study is basically the same as making instant drinks in general, such as seaweed instant drinks [4], ginger extract instant functional drinks [5], soursop leaf pollen instant drinks [6], instant jackfruit seed drinks [7], instant drink Noni leaf [8,9], and instant date palm juice drinks [10].

The making of traditional instant drinks has not implemented temperature control on a scheduled basis, so that the quality of the final product produced is not homogeneous, in fact it often occurs excess caramelization, resulting in a darker product color. An uncontrolled cooking temperature can also cause damage to sucrose due to the inversion process. Sucrose inversion occurs because of high temperatures and an overly alkaline $\mathrm{pH}[11]$.

Intensive stirring is necessary for the production of instant coffee, especially when the crystallization process begins. During crystallization, heat is released into the system, triggering caramelization and sugar inversion. After the recrystallization of sugar occurs completely, heat and stirring are still needed in order to obtain dry crystal granules [12]. Sugar recrystallization traps the mass of coffee that is around the sugar, therefore the final crystal contains coffee and also has the taste and aroma of coffee; known as instant coffee.

The crystallization method that uses sugar as its crystallizing agent is known as co-crystallization $[3,6]$. In this technique sugar acts as a coating material for coffee particles around it. Sugar recrystallization begins when the concentration of sucrose in solution is at supersaturated level. This stage is called the primary nucleation stage. In this situation, if the solution continues to cool the crystal core molecules will stick together and grow into larger crystals (secondary nucleation stage) $[13,2]$. When secondary nucleation starts, primary nucleation will be provoked and the crystallization process will proceed very quickly.

The purpose of the study was to determine the effect of heating-schedule (HS) on the physico-chemical properties of Liberika Tungkal Jambi instant coffee and to determine the optimal HS that produces the best quality of instant coffee.

\section{MATERIAL AND MethodS}

\section{A. Material and Equipment}

The main material used was coffee grounds, granulated sugar, and mineral water. Liberika Tungkal Jambi coffee powder (libtujam) was obtained from Parit Tomo Village, Betara District, Tanjung Jabung Barat Regency, Jambi Province. Refined sugar and mineral water was obtained from a supermarket in the city of Jambi. The main equipment used 
was the scale, coffee extractor, thermometer, gas stove, frying pan, stirrer, blender, refractometer, and glassware for analysis.

\section{B. Methods}

Instant coffee was made by the method of cocrystallization. The crystallizing agent used was sugar at a concentration of $25 \%$. Coffee extract was made using an extractor in a ratio of hot water/coffee powder of 15/1. Five levels of heating schedule (HS) treatment namely HS1, HS2, HS3, HS4, and HS5 were applied in a completely randomized design with 4 replications. The parameters observed were the physico-chemical properties of instant coffee products, including water content, ash content, $\mathrm{pH}$, solubility, and total dissolved solids. For the data obtained, analysis of variance and DNMRT was performed at a confidence level of $95 \%$.

Coffee extract was made using the method of Mursalin et al. (2018) [14]; $300 \mathrm{gr}$ coffee powder was placed in a coffee extractor and then added with $3000 \mathrm{ml}$ of $95^{\circ} \mathrm{C}$ hot water, stirred for 2 minutes, allowed to stand for 1 minute, then filtered to separate the pulp with the first extract. Furthermore, the pulp were added hot water again as much as $1500 \mathrm{ml}$, stirred for 1 minute, allowed to stand for 1 minute, then extracted again until the second extract was obtained. The first and second extracts were mixed and ready to be used as raw material for making instant coffee.

The cooking process in making instant coffee was divided into 5 stages, namely (1) preheating to reach the evaporation water temperature $\left(100-120^{\circ} \mathrm{C}\right)$ and removing some of the water from the coffee extract; (2) adding sugar to the coffee extract solution and thickening the mixture until the sugar concentration was reached at the saturation point (65\%); (3) prevent sugar caramelization by rapidly reducing the cooking temperature at $90^{\circ} \mathrm{C}$; (4) propagating the crystal core formation by slowly lowering the cooking temperature to $75^{\circ} \mathrm{C}$; and (5) allows the growth of the crystal core and at the same time dries the crystal to produce dispersed granules by keeping the cooking temperature at $75^{\circ} \mathrm{C}$. During the heating, intensive stirring was carried out. The temperature variation treatment at each cooking stage (HS) was repeated 4 times. In detail, the 5 types of HS were presented in Table 1 and the scheme could be seen in Figure 1.

TABLE I DETAILS OF THE 5 TYPES OF HS APPLIED

\begin{tabular}{cccccccccc}
\hline \multicolumn{2}{c}{} & \multicolumn{2}{c}{$\mathrm{HS}_{1}$} & \multicolumn{2}{c}{$\mathrm{HS}_{3}$} & \multicolumn{2}{c}{$\mathrm{HS}_{4}$} & \multicolumn{2}{c}{$\mathrm{HS}_{5}$} \\
\hline $\begin{array}{l}\text { Time } \\
(\text { Min. })\end{array}$ & $\begin{array}{l}\text { Temp. } \\
\left({ }^{\circ} \mathrm{C}\right)\end{array}$ & $\begin{array}{l}\text { Time } \\
(\text { Min. })\end{array}$ & $\begin{array}{l}\text { Temp. } \\
\left({ }^{\circ} \mathrm{C}\right)\end{array}$ & $\begin{array}{l}\text { Time } \\
(\text { Min. })\end{array}$ & $\begin{array}{l}\text { Temp. } \\
\left({ }^{\circ} \mathrm{C}\right)\end{array}$ & $\begin{array}{l}\text { Time } \\
(\mathrm{Min} .)\end{array}$ & $\begin{array}{l}\text { Temp. } \\
\left({ }^{\circ} \mathrm{C}\right)\end{array}$ & $\begin{array}{l}\text { Time } \\
(\mathrm{Min} .)\end{array}$ & $\begin{array}{l}\text { Temp. } \\
\left({ }^{\circ} \mathrm{C}\right)\end{array}$ \\
\hline 0 & 28 & 0 & 28 & 0 & 28 & 0 & 28 & 0 & 28 \\
9 & 100 & 10.5 & 105 & 12 & 110 & 13.5 & 115 & 15 & 120 \\
29 & 100 & 28 & 105 & 27 & 110 & 26 & 115 & 25 & 120 \\
32 & 90 & 31 & 90 & 30 & 90 & 29 & 90 & 28 & 90 \\
38 & 75 & 37 & 75 & 36 & 75 & 35 & 75 & 34 & 75 \\
53 & 75 & 53 & 75 & 53 & 75 & 53 & 75 & 53 & 75 \\
\hline
\end{tabular}

Note: HS=heating schedule

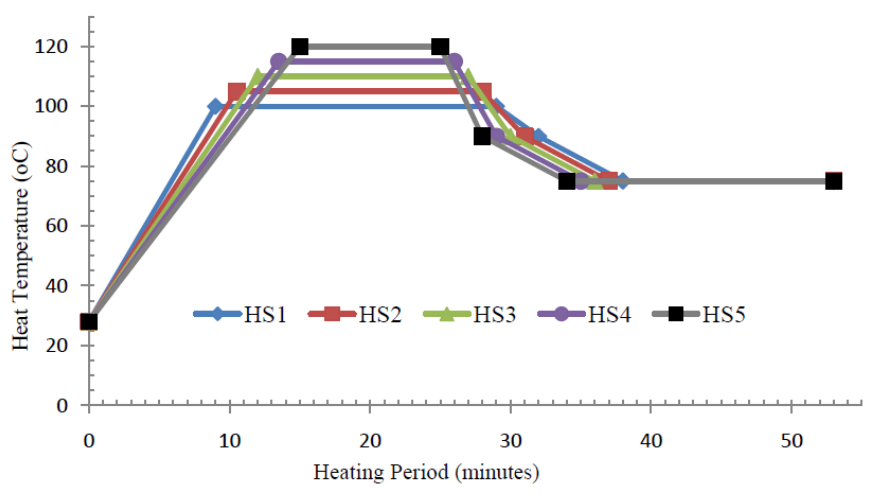

Fig. 1 Schematic of 5 types of HS applied

\section{RESUlT AND DisCUSSION}

The effect of HS on the physio-chemical properties of instant coffee Liberika Tungkal Jambi can be seen in Table 2.

TABLE 2

THE EFFECT OF HS ON THE PHYSIO-CHEMICAL PROPERTIES OF INSTANT COFFEE LIBERIKA TUNGKAL JAMBI

\begin{tabular}{llllll}
\hline $\begin{array}{l}\text { Heating } \\
\text { schedule }\end{array}$ & $\begin{array}{l}\text { Water } \\
\text { content } \\
(\%)\end{array}$ & $\begin{array}{l}\text { Ash } \\
\text { content } \\
(\%)\end{array}$ & $\mathrm{pH}$ & $\begin{array}{l}\text { Solubility } \\
(\%)\end{array}$ & $\begin{array}{l}\text { Total } \\
\text { soluble } \\
\text { solid } \\
\left({ }^{\circ} \text { Brix }\right)\end{array}$ \\
\hline HS1 & $1.72 \mathrm{a}$ & 6.16 & $5.50 \mathrm{~b}$ & $97.98 \mathrm{~d}$ & $8.41 \mathrm{c}$ \\
HS2 & $1.68 \mathrm{a}$ & 6.14 & $5.54 \mathrm{a}, \mathrm{b}$ & $98.17 \mathrm{c}$ & $8.47 \mathrm{~b}, \mathrm{c}$ \\
HS3 & $1.61 \mathrm{~b}$ & 6.13 & $5.56 \mathrm{a}, \mathrm{b}$ & $98.22 \mathrm{~b}$ & $8.51 \mathrm{a}, \mathrm{b}, \mathrm{c}$ \\
HS4 & $1.57 \mathrm{~b}$ & 6.12 & $5.59 \mathrm{a}$ & $98.25 \mathrm{a}, \mathrm{b}$ & $8.53 \mathrm{a}, \mathrm{b}$ \\
HS5 & $1.43 \mathrm{c}$ & 6.12 & $5.60 \mathrm{a}$ & $98.28 \mathrm{a}$ & $8.60 \mathrm{a}$ \\
\hline
\end{tabular}

Note: Numbers followed by different lowercase letters in the same column have a significant effect on the $5 \%$ level according to the DNMRT test; total soluble solids were measured after instant coffee powder was dissolved in water in a ratio of $1 / 10$

\section{A. Water Content}

Analysis of variance showed that the water content of instant coffee significantly affected by HS. An increase in heating temperature tends to reduce the water content of instant coffee. Further tests with DNMRT showed that cooking temperatures in the range $110-115^{\circ} \mathrm{C}$ produce moisture content (1.57-1.61\%), lower than cooking temperatures $100-105^{\circ} \mathrm{C} \quad(1.68-1.72 \%)$ and higher than cooking temperatures $120^{\circ} \mathrm{C}(1.61 \%)$.

It was found that the higher the cooking temperature was applied, the lower the water content of instant coffee produced. Heating caused the evaporation of water, the higher the temperature applied the more water evaporated. Therefore, cooking at high temperatures produce instant coffee with low water content. This was consistent with the statement of Nilasari et al. (2017) [15] and Fitriani et al. (2013) [16] that the higher the temperature and/or the longer the cooking time cause more water evaporate. The evaporation was also caused by the difference of vapor pressure between water in the material and water vapor in the air. Water vapor pressure in the material is generally greater than water vapor pressure in the air; as consequences, mass transfer of water from the material to the air had been occured. 


\section{B. Ash Content}

Ash content indicates mineral and metal content in a material. The mineral and metal content of ground coffee is influenced by the location of the coffee plant and does not change significantly during roasting. The mineral content of ground coffee is obtained from nutrients absorbed during growth [17]. Heating schedule had no significant effect on instant coffee ash content. Instant coffee cooked with a temperature range of $100-120^{\circ} \mathrm{C}$ produce ash content in the range of $6.12-6.16 \%$, has met the SNI standard for instant coffee $(6-14 \% \mathrm{w} / \mathrm{w})$ [21]

\section{C. $p H$}

Coffee contains several acids that are useful for forming the distinctive aroma and taste of coffee. The presence of these acids affects the degree of coffee acidity. Coffee with high acidity indicates that the coffee has good aroma and taste quality due to the existence of volatile acid compounds (forming aroma) and flavor forming acids [18]. Aromaforming acids in coffee include formic acid, acetic acid, propanoic acid, and hexanoic acid. Flavor-forming acids in coffee include acetic acid, malic acid, citric acid and phosphoric acid [18].

The $\mathrm{pH}$ of coffee ground before being made into instant coffee was in the range of 5.50-5.60. Analysis of variance showed that HS treatment had a significant effect on the $\mathrm{pH}$ of instant coffee. It was found that the higher the cooking temperature, the higher the $\mathrm{pH}$ of the product. It was estimated that cooking at high temperatures caused the amount of evaporated acid become more. Cooking temperatures of 100 , 105 , and $110^{\circ} \mathrm{C}$ produced instant coffee $\mathrm{pH}$ that was not significantly different with the $\mathrm{pH}$ range of 5.50-5.56.

\section{Solubility}

Solubility is the ease of instant coffee dissolves when added with hot water. Solubility is an important parameter and is a requirement for instant drinks. The higher solubility means that the less pulp is involved in the brewing product.

It was known that HS had a significant effect on the solubility of instant coffee. The higher the cooking temperature, the higher the solubility of instant coffee. The highest solubility of instant coffee was produced by the cooking temperature of $120^{\circ} \mathrm{C}$ with a value of $98.28 \%$. Cooking temperature of $115^{\circ} \mathrm{C}$ produces instant coffee with a solubility of $(98.22 \%)$, not significantly different from that produced from cooking temperature of $110^{\circ} \mathrm{C}(98.25 \%)$.

\section{E. Total Soluble Solid}

Total soluble solid instant coffee was observed after coffee was brewed with hot water in a ratio of 1:10 (ten grams of instant coffee powder was dissolved in hot water until the volume of the solution become $100 \mathrm{ml}$ ). HS significantly affected the total soluble solid instant coffee. Total soluble solid resulted from HS3, HS4, and HS5 were 8.51, 8.53 and $8.60{ }^{\circ}$ Brix, respectively. All these value were not significantly different according to DNMRT at the $95 \%$ confidence level.
It found that the higher the cooking temperature, the higher total soluble solid instant coffee. According to Heldman (2012) the higher and the longer the cooking, the evaporation of free water in the product would be higher [19]. At high evaporation, the water content dropped so intensely so the percentage of total soluble solid tended to increase. The heating process affected the total soluble solid mainly due to the decrease in water content of the product; as a consequence, the percentage of total soluble solid increased. This was in accordance with the statement of Agus (2012) which stated that, the evaporation of water during heating caused water levels to decrease and the concentration of solids increased [20]. Decreasing the water content would also increase the level of other nutrients.

Brix degree is the percentage of dry solids dissolved in a solution that is calculated as sucrose. The degree of Brix can also be defined as the percentage of the mass of sucrose contained in the mass of the solution. While the mass of sucrose solution is the mass of sucrose plus the mass of the solvent. In this study the degree of Brix was determined by a refractometer from a solution of instant coffee powder with a concentration of $10 \%$. Thus the higher the measured degree of Brix means the lower the content of the coffee extract. The Brix degree produced from the HS3, HS4, and HS5 were 8.51, 8.53 and $8.60{ }^{\circ}$ Brix, respectively, which means that the coffee extract content of each treatment was estimated at 1.49, 1.47, and $1.40 \%$.

\section{F. The Effective and Efficient $H S$}

The results of data analysis showed that HS3 was an effective and efficient HS for making instant coffee with the co-crystalization method. HS3 produced instant coffee with a moisture content of $1.57-1.61 \%$; ash content $6.12-6.16$; $\mathrm{pH}$ 5.50-5.60; solubility 98.22-98.25; and total soluble solid 8.47$8.53{ }^{\circ}$ Brix

The physico-chemical of Liberika Tungkal Jambi instant coffee produced by the co-crystallization method using HS3, generally met the quality standards set by SNI. Comparison of SNI quality standards and quality of instant coffee produced by HS 3 could be seen in Table 3 .

TABLE 3

COMPARISON OF SNI QUALITY STANDARDS AND QUALITY OF INSTANT COFFEE PRODUCED BY HS3

\begin{tabular}{lllll}
\hline Nu. & Parameters & Units & $\begin{array}{l}\text { Quality Standard } \\
\text { SNI 2983:2014* }\end{array}$ & $\begin{array}{l}\text { HS3 Product } \\
\text { Quality }\end{array}$ \\
\hline 1 & Appearance & & & Normal \\
1.1 & Aroma & - & Normal & Normal \\
1.2 & Colour & - & max. 4.0 & 1.61 \\
2 & Water & $\%(\mathrm{w} / \mathrm{w})$ & $6-14$ & 6.13 \\
3 & Ash & $\%(\mathrm{w} / \mathrm{w})$ & $6-5$ & - \\
4 & Kafein & $\%$ & 2.5 & 30 second/ \\
5 & Solubility & - & 30 second/ & 1.9 minute \\
\hline Note: & $*$ Badan Standarisasi Nasional, 2014 [21] &
\end{tabular}




\section{CONCLUSION}

HS significantly affected water content, $\mathrm{pH}$, solubility, and total soluble solid instant coffee, but not for ash content. Cooking with $\mathrm{HS} 3$, namely heating at $110^{\circ} \mathrm{C}$ at the beginning of cooking, followed by $90^{\circ} \mathrm{C}$ at the beginning of crystallization, and $75^{\circ} \mathrm{C}$ when the crystal growth, produced instant coffee with a moisture content of $1.57-1.61 \%$; ash content 6.12-6.16; $\mathrm{pH}$ 5.50-5.56; solubility 98.22-98.25; and total soluble solid $8.47-8.53{ }^{\circ}$ Brix.

\section{ACKNOWLEDGMENT}

We would like to thank the Chairperson of Jambi University LPPM for research funding and also to all those who support the works.

\section{REFERENCES}

[1] Angria M. 2011. Pembuatan Minuman Instan Pegagan (Centella asiatica) Dengan Cita Rasa Cassia Vera. Skripsi Fakultas Teknologi Pertanian. Universitas Andalas. Padang

[2] Setiyoningrum P. 2011. Pembuatan Coro Instan Minuman Khas Pati Jawa Tengah (Skripsi). Bogor: Institut Pertanian Bogor.

[3] Chen AE, Viega MF, Rizutto AB. 1991. Cocrystalisasi, An Encapsulation Process, Food tech, 24, $1991:$ 289-297.

[4] Wibowo L, E. Fitriyani. 2012. Pengolahan Rumput Laut (Eucheuma Cottoni) Menjadi Serbuk Minuman Instan. Jurusan Ilmu Kelautan dan Perikanan, Politeknik Negeri Pontianak.

[5] Rifkowaty EE, Martanto. 2016. Minuman Fungsional Serbuk Instan Jahe (Zingiber officinalerosc) dengan Variasi Penambahan Ekstrak Bawang Mekah (Eleutherine americana Merr) Sebagai Pewarna Alami. Jurnal Teknik Pertanian Lampung Vol. 4, No. 4:315-324.

[6] Ramadina A. 2013. Pengaruh Penggunaan Jumlah Gula Terhadap Karakteristik. Inderawi Minuman Instan Serbuk Sari Daun Sirsak (Annona Muricata L). [Skripsi]. Fakultas Teknik Universitas Negeri Semarang. 105 halaman.

[7] Nusa MI, M Fuadi, S Fatimah. 2014. Studi Pengolahan Biji Buah Nangka Dalam Pembuatan Minuman Instan. Agrium Volume 19 (1). Hal 31-38.
[8] Yuliawaty ST, WH Susanto. 2015. Pengaruh Lama Pengeringan dan Konsentrasi Maltodekstrin Terhadap Karakterisktik Fisik Kimia dan Organoleptik Minuman Instan daun Mengkudu (Morinda citrifolia L) Jurnal Pangan dan Agroindustri 3(1): 41-52.

[9] Sitompul N. 2014. Pengaruh Perbandingan Sari Mengkudu Dengan Sari Nanas Dan Jmlah Sukrosa Terhadap Mutu Minuman Serbuk Mengkudu Instan. Ilmu dan Teknologi Pangan. Jurnal Rekayasa Pangan Dan Pertanian.,Vol.2 No.1.

[10] Bachtiar. 2011. Pembuatan Minuman Instan Sari Kurma (Phoenix Dactylifera). Skripsi. Fakultas Teknologi Pertanian. Institut Pertanian Bogor. Bogor.

[11] Maharani DM, R Yulianingsih, Y Sugiarto, SR Dewi, N Komar, DW Indriani. 2013. Pengaruh Suhu Pemasakan dan $\mathrm{pH}$ Nira dengan Menggunakan Teknologi Vakum Terhadap Kulaitas Gula Merah Tebu. Laporan Penelitian, FTP, UB, Malang.

[12] Latief AS, R Syarief, B Pramudya, Muhadiono. 2010. Peningkatan Mutu Gula Tumbu Melalui Metode Sulfitasi Dalam Laboratorium. Jurnal Gema Teknologi Vol 16, No 1 Periode April 2010-Oktober 2010. Institut Pertanian Bogor.

[13] Earle RL. 2000. Unit Operation In Food Processing, Pergamen Press, New York.

[14] Mursalin, A Nizori, I Rahmayani. 2018. Teknologi Produksi Kopi Instan Liberika Tungkal Jambi dengan Metode Kristalisasi. Laporan Penelitian, Fateta Unja, Jambi. (Tidak dipublikasikan)

[15] OW Nilasari, WH Susanto, JM Maligan. 2017. Pengaruh Suhu dan Lama Pemasakan Terhadap Karakteristik Lempok Labu Kuning (Waluh). Jurnal Pangan dan Agroindustri Vol.5 No.3:15-26.

[16] Fitriani S, A Ali, Widiastuti. 2013. Pengaruh suhu dan lama pengeringan terhadap mutu manisan kering jahe (Zingiber Officinale Rosc.) Dan Kandungan Antioksidannya. Jurnal Sagu, Vol. 12 No. $2: 1-8$.

[17] Martin MJ, F Pablos, AG Gonzales. 1999. Characterization of arabica and Robusta roasted coffee varieties and mixture resolution according to their metal content. Food Chemistry 66: 365-370 39

[18] Panggabean E. 2011. Buku Pintar Kopi. AgroMedia Pustaka, Jakarta.

[19] Heldman (2012)

[20] Agus MI. 2012. Pengaruh Suhu dan Lama Waktu Ekstraksi Terhadap Sifat Kimia dan Fisik Pada Pembuatan Minuman Sari Jahe Merah dengan Kombinasi Penambahan Madu Sebagai Pemanis. Jurnal Pangan dan Agroindustri 3(2): 530-541

[21] Badan Standarisasi Nasional (BSN). 2014. SNI Kopi Instan. SNI 2983:2014. 